\title{
EMPOWERING DECISION MAKERS TO AVOID THE OVERSIZING OF BUILDING SERVICE SYSTEMS
}

\author{
Jones, Darren Anthony; Eckert, Claudia Margot
}

The Open University

\begin{abstract}
Oversizing of building service systems has a direct impact on building efficiency and operational costs. The research of this paper highlights several major contributors to the issue of oversizing. A key factor is the excessive and uncoordinated application of design margins applied during the multiple stages of a building services project; others include, a lack of communication and transparency across the various stakeholder groups, and the use of vague or unreliable data upon which initial project requirements are based. The impact of these factors on system performance and cost, and how these can impede on a building's ability to meet energy efficiency targets are analysed and discussed.

The paper emphasises the need to develop robust processes that capture the scope and rationale for the margins applied, and to communicate this knowledge in a clear and unambiguous format, to all project stakeholders. The development of flexible and alternative design solutions that apply diversity principles, such as different backup systems to provide resilience rather than the traditional 'like-forlike' redundancy solutions, are also explored.
\end{abstract}

Keywords: Design process, Case study, Decision making, Design margins, Energy efficiency

\section{Contact:}

Jones, Darren

The Open University

STEM-EI

United Kingdom

darren.a.jones@open.ac.uk

Cite this article: Jones, D.A., Eckert, C.M. (2019) 'Empowering Decision Makers to Avoid the Oversizing of Building Service Systems', in Proceedings of the 22nd International Conference on Engineering Design (ICED19), Delft, The Netherlands, 5-8 August 2019. DOI:10.1017/dsi.2019.119 


\section{INTRODUCTION}

Over-engineering of building service systems is often a hidden source of inefficiency that can significantly add to building operational costs, and reduce the sustainability of systems (Bacon, 2014). This paper provides an overview of the issue of overdesign in building services that results from the excessive and uncoordinated application of design margins. It will discuss the impact these margins have on system performance and cost, and how these can impede on a building's ability to meet energy efficiency targets, particularly in the context of large commercial buildings and hospitals, that will almost certainly have carbon reduction targets associated with them. One principle cause of this overengineering is a cumulative effect of different stakeholders adding margins to the requirements and the specification of the system to mitigate against their own risks (CIBSE, 1998). The design stakeholders often know that their system is overdesigned, but not by how much; this is generally of no concern to the building service consultants or wider project team, as most building service systems operate at part-load, not at maximum capacity. Hence from a 'risk' perspective, the scenario of oversizing actually works in the design engineers' favour, providing a safety buffer when building performance data, such as thermal peak load requirements, are not identified. The down side to this 'safe' design condition, is that this will undoubtedly impact on the organisations ability to meet its 'legally-binding' carbon reduction targets, as the over-sized engineering system will be incapable of operating at its optimum performance. Avoiding oversized systems is therefore particularly important, as this will not only impact on the building's ability to meet the energy efficiency targets but will also become an economic burden on the building owner/occupier, due to increased operating, maintenance and repair costs (Jones et al., 2018). A key aim of this paper is to suggest and discuss possible avoidance strategies, that if adopted will prevent the oversizing of building service systems during the specification, design and installation phases of a project. Building on empirical research looking at margins incorporated into building service systems within hospitals, the development of more systematic processes for capturing, managing and deciding on margins during the planning, design and installation phases of building services project will be explored. The paper is presented in several distinct sections. Section two provides a literature review of various themes that have an influence and impact upon the issue of oversizing. Section three provides a précis of the research methodology. Section four discusses stakeholders and communication in building services design. Section five reflects on various case study examples of over-capacity building service systems and discusses the efficiency and financial consequences of the oversizing. Avoidance methods to prevent oversizing and alternative or flexible building service systems with suitable margins are considered in section six. Discussion points and contributions will be presented in section seven, and further work and conclusions will be drawn in section eight.

\section{LITERATURE REVIEW}

The literature covers various issues, all of which have an impact on, or in the case of UK and International carbon reduction targets, are impacted by, the oversizing of building service systems. The review begins with an overview of the problem and then moves onto the various topics where the excessive inclusion of design margins, imprecise design guides, system risks and the need for flexibility, all have an influence on the oversizing issue.

\subsection{Research problem overview}

The paper focusses on oversized building service systems (e.g. heating, cooling and ventilation systems) often found in commercial buildings; specifically, hospital buildings. An empirical study carried out by Jones et al. (2016, 2017, 2018), complementing similar findings by Peeters et al. (2008), Djunaedy et al. (2011), and Bacon (2014) showed that overdesign by several hundred percent can result from the excessive application of various 'design margins' across the specification, design and installation phases of a project. Design margins are often added by multiple stakeholders throughout the design process, very often through habit, custom and practice as precautionary measures against perceived risks without any real thought of the consequences of 'oversizing' (CIBSE, 1998). The pressure on hospital systems is particularly large, because they need to maintain services under very strenuous circumstances, such as the recent UK heatwave, when cooling and increased patient numbers from heat-related conditions placed a much greater demand on chilled water and refrigeration systems to be resilient. Margins are 
particularly important when considering their impact on energy efficiency; essentially, the addition of margins within engineering design can be considered the converse of optimisation. The Climate Change Act 2008 currently provides a strong legal necessity to properly ensure energy infrastructure within hospital buildings operates at the optimum conditions for efficiency, yet the fear of individuals or groups to be held responsible for the lack of building service provision (e.g. power and thermal requirements) is leading to significantly over-engineered, over-sized plant that is incapable of operating at its optimum efficiency point. Over-engineered building service systems cost UK hospitals millions of pounds each year in lost revenue, resulting from the initial capital outlay of over-dimensioned plant and equipment, through to its ongoing operating, maintenance and repair costs. Previous research suggests that excess costs associated with oversizing of energy infrastructure ranges from 10-33\% (Peeters et al., 2008; Djunaedy et al., 2011). Findings from costed scenarios presented in this paper would, however, suggest that this excess cost range is rather conservative.

\subsection{UK energy efficiency and carbon reduction targets}

Energy efficiency in buildings and infrastructure design is necessary to deliver a low carbon future in line with the UK Climate Change Act 2008, which set trajectory targets for the reduction in net national carbon emissions "by at least $80 \%$ by $2050 \ldots$ against a 1990 baseline" (NHS Sustainable Development Unit, 2013). With regard to hospital organisations, despite some improvements in clinical efficiency, the UK National Health Service (NHS) has increased its carbon footprint by $40 \%$ since 1990. Hence "there is now clear evidence that demonstrates that NHS hospitals are failing to achieve the performance required by the UK Government" (Bacon, 2014).

\subsection{An overview of design margins}

Design margins is an overarching term that is used to describe the multiple contingencies added to the design or the design requirement during the design process to provide flexibility, resilience and safety (Eckert and Isaksson, 2017). Different terms, such as safety factor, excess or buffer are used to use to denote different purposes for the element of a design that exceeds the functional requirements (Eckert et al., 2013). While the term 'margin' is often used within companies in a number of industry sectors, particularly in the aerospace or ship building industry (Stratmann, 2006), it has so far not been formally defined. A useful definition of a design margin is: "the extent to which a parameter value exceeds what it needs to meet its functional requirements regardless of the motivation for which the margin was included" (Eckert et al., 2013); design margins are added by different stakeholders for a variety of reasons. From the perspective of overdesign, Tackett et al. (2014) address margins in the context of shipbuilding in terms of excess, as "the quantity of surplus in a system once the necessities of the system are met" and capacity as "the ability of a system to meet future performance objectives using existing system excess". With regard to building services, whilst design margins are frequently applied to "future proof' the system; the primary reason for their application is to safeguard against uncertainty and risk (CIBSE, 1986). Bacon argues "that building energy performance directly relates to the engineer's assumptions based upon occupancy levels, which are often standardised, leading to over-engineered systems for maximum occupancy levels" (Bacon, 2014). Often "many decisions are made at detail level, with limited consideration of overall solutions and overall performance/cost ratio" (Almefelt, 2005).

\subsection{Design margins in practice and published guidance}

Design engineers rely upon building service design guides for reference. Whilst a large range of margin values are quoted within these documents for various scenarios, there is no real guidance on how best to apply the margins. An industry research report published by the Chartered Institute of Building Services Engineers revealed that design margin values used for similar applications varied considerably across multiple documents (CIBSE, 1998). The report emphasised that whilst guidance publications often quote typical margins values, they do not make any specific recommendations for their use. The research also revealed that the origin of many margins quoted were difficult to determine, pointing to a degree of "custom and practice" built up over time. Bownass in his 2001 book states that "there is little authoritative reference on the actual margin to be applied in any specific application and although there are good reasons to applying design margins (installation tolerances, theoretical fabric design $\mathrm{U}$ values, etc.) that any objective figure can be debated" (Bownass, 2001). Other research suggests "the widespread use of simple sizing tools "previous experience" and rules-of-thumb, could be an indication of why 
oversizing is so prevalent" (Djunaedy et al., 2011). Hence, this paper challenges the current use of standardised assumptions and 'rules of thumb' estimates that lead to excessive margins, and aims to provide some insight into how this practice can be managed more effectively.

\subsection{System redundancy and the adoption of alternative systems (diversity)}

Design for flexibility principles aim at changes to the operation conditions and requirements; redundancy principles aim at handling failure in the current system (Chen and Crilly, 2014). The application of a redundancy factor within building services design to ensure reliability in the event of a full or partial system failure also has a significant impact on system sizing; having more boilers than is necessary to meet the site thermal requirements is an example of system redundancy. The adoption of this principle should, however, be applied with care, as the application of excessive redundancy could lead significantly oversized systems and operational inefficiencies (e.g. losses attributed to semi-dormant equipment in 'standby' mode). Typically, redundancy scenarios utilise building service systems on a like-for-like basis, rather than consideration being given to the use of alternative technologies. Using an alternative system to provide an element of resilience is the related concept of diversity (Möller and Hansson, 2008). A simple example of the use of diversity would be to provide localised electric heaters to critical areas of a hospital when centralised heating systems fail, rather than 'doubling up' on the main centralised systems.

\subsection{Risk and resilience}

The management of margins, as a means to handle risk, needs to be seen in the wider context of resilience on two related levels. Firstly, the ability of the building to function within specified parameters; therefore resilience is provided by maintaining specific operating conditions. Where the system is impacted by some form of previously envisaged disturbance, the system's resilience is measured by its speed and ability to return to its original state (Dieter, 1989). Such systems may fail catastrophically under unforeseen circumstances (Weick et al., 1999). And secondly, the resilience of the overall system to maintain its core functions, i.e. to provide adequate medical care. Resilient systems may include multiple approaches to service provision, such as generators using different fuels; redundancy or spare capacity; and the use of experienced, trained management, empowered to act competently in an emergency.

\subsection{Flexibility in design}

Design margins are often added to provide the flexibility required for future changes (Banerjee and de Weck, 2004), flexibility itself being defined as providing "functionality, performance, and capacity". Future changes in respect to building service systems can include changes in the operating conditions, such as the recent heat wave, or changes in demands, such as refurbishments or the addition of new buildings. In the context of refurbishments, margins are thought of as excess which can be utilised by designers to meet new requirements (Tackett et al., 2014). De Neufville et al. (2006) advocate design options, whereby margins are designed into a system upfront at a comparatively low cost in anticipation of future changes or upgrades that can already be foreseen, such as an additional floor on a parking garage. Incorporating flexibility into engineering design can support changes in future requirements, however, this will inevitably introduce a degree of overdesign into the product or system (Ross and Hastings, 2005).

\section{RESEARCH METHODOLOGY}

The issue of hospital engineering systems overdesign within the context of this paper originated from wider $\mathrm{PhD}$ research looking at strategic energy management in Hospital Trusts. The first author has over 30 years' experience of working in energy management. Whilst section 4 makes reference to an oversized boiler system case study, the specific methodology associated with this work is cited within the author's previous papers (Jones and Eckert 2016, 2017, 2018). Building on this, further mixed methods that include semi-structured interviews, document analysis and a wider review of relevant literature has been undertaken to determine whether the oversized boiler case study example was an isolated case, or if indeed, this is a universal problem that extends to many other types of building service systems. Two semi-structured interviews were undertaken with experienced building service design consultants via telecom calls, during November 2018. Notes were taken during the calls, capturing the 
salient points discussed. The interviews provided a useful overview of the applied use of the RIBA 'plan of work' but also supported the development of Figure 1. In addition to the research interviews, a document review was undertaken across 25 building service 'energy audit' reports to establish the scope of oversizing associated with various building service systems; these documents were acquired from a chartered engineering practice, linked to the first author. Building 'energy audit' reports were specifically selected for this research as plant oversizing is inherently known to have a negative impact on energy performance, hence any such cases are inevitably reported along with supporting economic impact calculations. The document review was carried out using key 'word' searches (e.g. overcapacity, oversizing etc.) via programme toolbars, within a pdf. reader and MS Word. Where relevant building service examples were identified, these were studied in greater detail to deduce the average oversizing factor and related economic impact range, applicable to each. The document review resulted in six major building service groups being identified. The results of the document review were combined with previous research undertaken by BSRIA across 50 heating, ventilation and cooling systems within the UK (Crozier, 2000) that informed the development of a comparative illustration of six building service system types, which is presented in Figure 2. A wider review of literature associated with building services overdesign, was also undertaken. Despite the BSRIA study being undertaken in 1999, there is still clear evidence that over-sizing of building services systems remains a significant issue. The case study relating to the oversized ventilation system (section 5) was undertaken during April 2017. This involved a technical review of the system, using calibrated instruments to determine system air flow rates and absorbed power readings. A review of relevant literature was also undertaken to establish the necessary requirements for critical ventilation systems. The outcome of measurements and observations were subsequently used to determine the efficiency of the system using engineering calculations.

\section{STAKEHOLDERS \& COMMUNICATION IN BUILDING SERVICES DESIGN}

The number of stakeholders involved in a commercial building service design project can be significant. Previous research looking at the design of a hospital boiler system identified in excess of 60 stakeholders (Jones et al., 2018). Multiple stakeholders bring different priorities and viewpoints, potentially leading to conflicting needs. The structure and number of stakeholders can often change throughout the duration of a project; some stakeholders may only be involved briefly, to provide specialist knowledge, components or services, whilst others, such as the client, project managers and lead consultants may be involved across the duration of the project. Figure 1. is a modified diagram of the RIBA 'Plan of Work' (RIBA, 2013) that provides a simplified illustration of typical stakeholders and work stages relative to a commercial building services design project, along with core objectives and priorities.

\begin{tabular}{|c|c|c|c|c|c|c|c|c|}
\hline \multirow{3}{*}{$\begin{array}{l}\begin{array}{l}\text { Overseeing } \\
\text { Stakeholders }\end{array} \\
\text { Key Stakeholders } \\
\text { Work Stages } 0 \text { - } 7\end{array}$} & \multicolumn{2}{|c|}{ Internal Project Manager } & \multicolumn{5}{|c|}{ Project Architect / Internal Project Manager } & \multirow{3}{*}{\begin{tabular}{|l} 
The Client \\
$\begin{array}{r}\text { Building } \\
\text { Occupants }\end{array}$ \\
$\begin{array}{l}7 \\
\text { In Use }\end{array}$
\end{tabular}} \\
\hline & The Client & $\begin{array}{c}\text { Client } \\
\text { Representative }\end{array}$ & \multicolumn{3}{|c|}{ Design Consultants - 1, 2 or 3 Main Participants } & $\begin{array}{l}\text { Installation } \\
\text { Contractor }\end{array}$ & $\begin{array}{l}\text { Commissioning } \\
\text { Engineers }\end{array}$ & \\
\hline & 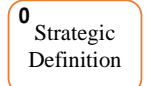 & $\begin{array}{l}1 \\
\text { Preparation } \\
\text { and Brief }\end{array}$ & $\begin{array}{l}2 \\
\text { Concept } \\
\text { Design }\end{array}$ & $\begin{array}{l}3 \\
\text { Developed } \\
\text { Design }\end{array}$ & $\begin{array}{l}4 \\
\text { Technical } \\
\text { Design }\end{array}$ & \begin{tabular}{|l|}
5 \\
Construction
\end{tabular} & $\begin{array}{c}6 \\
\text { Handover and } \\
\text { Close Out }\end{array}$ & \\
\hline $\begin{array}{l}\text { Core Objectives } \\
\text { and Priorities }\end{array}$ & $\begin{array}{l}\text { Client business } \\
\text { case outlining } \\
\text { core project } \\
\text { requirements. }\end{array}$ & $\begin{array}{l}\text { Develop } \\
\text { project } \\
\text { objectives and } \\
\text { outcomes. Set } \\
\text { project budget } \\
\text { and initial } \\
\text { project brief. }\end{array}$ & $\begin{array}{l}\text { Prepare concept } \\
\text { design including } \\
\text { outline proposals } \\
\text { for building } \\
\text { service systems. } \\
\text { Develop final } \\
\text { project brief. }\end{array}$ & \begin{tabular}{|l|} 
Prepare \\
developed design \\
including updated \\
proposals for \\
building services. \\
Provide cost \\
information.
\end{tabular} & $\begin{array}{l}\text { Prepare technical } \\
\text { design including } \\
\text { building services } \\
\text { information and } \\
\text { specialist sub- } \\
\text { contractor design } \\
\text { and specification. }\end{array}$ & $\begin{array}{l}\text { Offsite } \\
\text { manufacturing } \\
\text { and onsite } \\
\text { construction. }\end{array}$ & $\begin{array}{l}\text { Onsite } \\
\text { commissioning. } \\
\text { Handover of } \\
\text { building and } \\
\text { conclusion of } \\
\text { building services } \\
\text { contract. }\end{array}$ & $\begin{array}{l}\text { Undertake in } \\
\text { use services. }\end{array}$ \\
\hline
\end{tabular}

Figure 1. Simplified diagram of stakeholders, work stages, core objectives and priorities

The two semi-structured interviews provided a good insight as to the key stakeholders typically involved in a building services project, but also the standard approaches taken to meet the required outcomes of the various 'RIBA' work stages; limitations of the plan were also discussed. From this, it was interesting to note that some work stages are often combined, for example, the strategic definition and the preparation and brief are often undertaken together. Discussions with the consultants also revealed that the concept, developed and technical designs in respect to building services, are very often undertaken by the same engineering design consultancy to provide consistency across the various work stages. It was also advised that during larger construction projects, there is a greater likelihood that the three 'design' 
work stages may be undertaken by different consultancy practices, thus leading to the risk of ambiguity, conflict and contradiction in respect to the overall design intent. The construction work stage from a 'building services' perspective relates to the project installation, which from the experience of the consultants interviewed is generally overseen by a main contractor but often undertaken by multiple specialist sub-contractors. The penultimate work stage 'handover and close out' relates to the commissioning, snagging (an expression used to identify and record minor defects or omissions, for the contractor to rectify) and client handover, which from the interview discussions is often compromised due to time constraints resulting from impending deadlines, and the potential risk of financial penalties, should the handover be delayed. The 'in use' work stage relates to the ongoing use of building services plant until its end of life, disposal and replacement; typically, this can range from 5 to 25 years, dependant on the equipment type, its state of maintenance, its location and its utilisation. An interesting observation from the discussions and the perspective of both consultants was that there was rarely a feedback loop provided from the 'in use' work stage, back to any of the former work stages, thus preventing any lessons to be learnt regarding the final sizing outcome, compared to the initial brief.

Work stages illustrated in figure 1 develop from left to right. What is interesting, however, is that no stakeholder group has visibility over all work stages, and whilst the project architect has an overall responsibility to ensure the project is delivered to specification and on time; due to the broad job role, it is highly unlikely that this person will be involved in any of the sizing detail. In addition, due to the relative flow of work between the design, installation and commissioning groups, there is no ability to challenge the scope of margins applied, once these have been introduced by each group, and the design/installation has moved to the next stage. In essence, each group works to meet its own objectives without any thought as to what has been applied previously, hence another contributing factor to the issue of overdesign. In practice, some of the work stages illustrated may be carried out simultaneously; it is also important to note that this figure is a significant simplification of what is a very complex and fragmented design process. In addition to the oversizing issue, the potential lack of communication can create misunderstanding; for example, different stakeholder groups may try to achieve different or inconsistent goals, and where instructions and role definitions are not clear, or are inconsistent, conflicts could arise impacting on project progress. Further challenges can also arise when a client has multiple internal stakeholders. For example, within a large complex organisation such as a hospital, where a clinician arguing the need for energy intensive air conditioning and mechanical ventilation systems for their newly built treatment centre, maybe at conflict with the energy manager whom only aspires to meet minimum environmental standards, thereby having a positive impact on building energy performance.

\section{EXAMPLES OF OVERDESIGN}

It is evident from the research, that oversizing is an inherent problem across many types of building service systems. Following on from a case study example of an oversized boiler system (Jones et al., 2018), a further example of oversizing in respect to a hospital ventilation system is presented. An overview of other building services oversizing scenarios, are also illustrated.

\subsection{Case study example - ventilation system overdesign}

This case study example of an overdesigned hospital mechanical ventilation system presents a scenario that is very prevalent in new hospital buildings and other large commercial buildings, such as offices (Djunaedy et al., 2011). The absorbed fan power of ventilation systems in modern hospitals account for up to $12 \%$ of the total hospital electricity usage (Carbon Trust, 2010). Hospital design parameters require ventilation systems to be selected to meet a minimum air change rate (ACR) for general areas of 6 air changes per hour for bacterial contaminant dilution (Department of Health, 2013). Each fan has an inherent capacity range that is dependent on system pressure. As exact system pressures are difficult to deduce at the design stage, fan unit selections are typically oversized to ensure required air-flow rates can be met. This case study refers to a ventilation system serving an outpatient's department. Based on measured air-flow rates, it was possible to conclude that 10.6 air changes per hour (ACH) was supplied, thus exceeding the $6 \mathrm{ACH}$ required by the Department of Health. Due to the non-linear relationship between the fan speed and power consumed by the system (the cube law), it was possible to establish through the use of engineering calculations that should air-flow rates be reduced from 10.6 to $6.0 \mathrm{ACH}$, the corresponding power consumption would reduce by $82 \%$, thus saving in the region of $£ 22 \mathrm{k}$ per year in energy costs. This example clearly demonstrates the financial impact of the oversizing issue. 


\subsection{Other examples of system oversizing}

Wider research looking at other building service systems, other than just boilers and ventilation plant, concludes that oversizing is a universal problem that impacts on other building service systems, such as; water chillers, comfort cooling units (DX refrigeration units), distribution pumps and hot water calorifiers. Figure 2 below illustrates the 'scope of oversizing' relative to the various system examples found in the literature, and from a document analysis referred to within the methodology section 3.

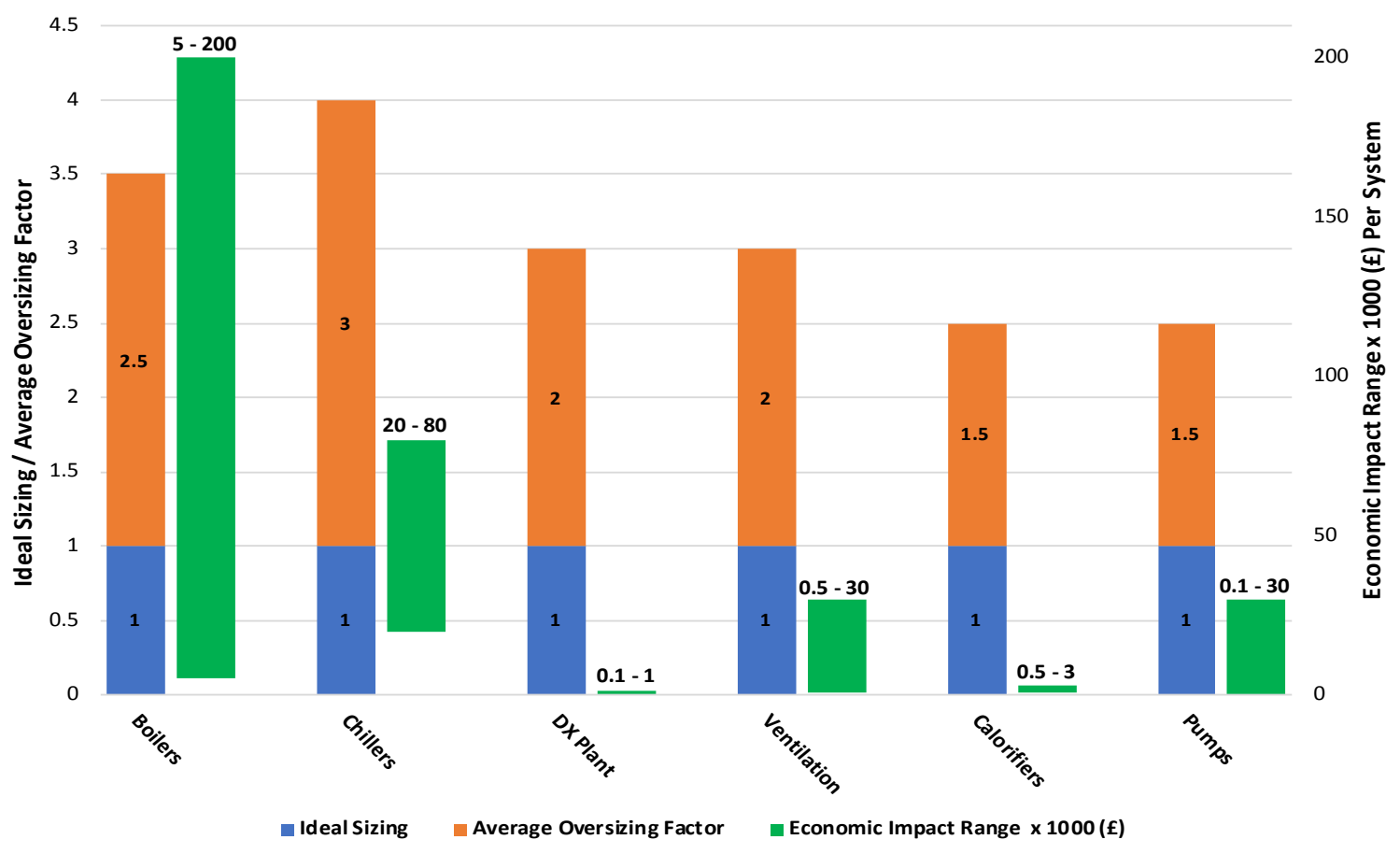

Figure 2. The problem of oversizing relative to various building service systems

The above figure presents six system types. The blue bars indicate ideal sizing; the orange bars illustrate average oversizing factors that range from 1.5 to 3 . The figure also provides a visualisation of the consequential outcomes of the oversized systems in annual economic terms; this has been based on various hospital empirical examples and calculations, taken from building service 'energy audit' reports.

\section{AVOIDANCE METHODS TO PREVENT OVERSIZING}

It is evident from the research undertaken that there are three key contributors to the problem of oversizing. Firstly, the un-coordinated and mismanagement of margins applied across the various RIBA stages 0 through to 5; secondly, a lack of effective communication between the various stakeholders and decision groups across each of the RIBA work stages; and finally, vague or unreliable data upon which the initial project requirements (client specification) is based.

\subsection{The requirements (client specification) - RIBA Stages 0 \& 1}

The client specification is the starting point of any building services design project. This specification dictates the requirements of the project that includes a list of deliverables incorporating; a technical specification, the use of preferred suppliers, delivery timelines and general terms and conditions of the project, this document is then issued to an M\&E design consultancy upon which a detailed engineering design is developed. From empirical experience which is supported by previous research (Bacon, 2014; CIBSE, 1998) the client specification (sometimes referred to as the client brief) particularly in hospitals, is often based on poor or incomplete data and client assumptions relating to building occupancy numbers, building use, future needs etc. It is therefore acknowledged that even at this early stage of project development, the client or client representative will 'err on the side of caution' and include some contingency margins that are hidden within the requirements specification. For this reason, there is an absolute necessity for this document to be clear and unambiguous, it should provide concise details as to the size of margins added, as well as the rationales for their inclusion. Any assumptions relating to occupancy levels, future use etc. should be clearly stated, as should any redundancy principles applied. 


\subsection{Engineering design margins (the consultants) - RIBA Stages 2, 3 \& 4}

Building service consultants at the detailed design stage will, as a matter of 'custom and practise', apply precautionary margins to offset any potential liability or financial penalties that may be imposed on them as a result of not meeting the necessary requirements. Whilst an engineering consultancy is unlikely to be penalised because it has oversized a building services system; a design that is undersized and unable to meet, for example, the thermal requirements of a hospital building, poses a far greater risk to the M\&E consultancy in terms of potential litigation. Hence, from both a risk and financial perspective (the larger the project, the larger the fees) there is a strong vested interest for designers to ensure that client capacity requirements are not only met, but exceeded. Cautionary margins applied by design consultants include those that mitigate risk impacts such as plant breakdown (redundancy margins), extreme weather conditions, wear and tear on equipment, uncertainties in calculation software, poor data use and client assumptions. Various design options are available to building service consultants that safeguard against risk, but at the same time help to avoid the oversizing problem. One such option is modular design; this involves the specification of many smaller units that collectively meet peak requirements whilst providing greater flexibility and performance during periods of reduced load. Other benefits associated with this type of arrangement is that 'stand-by' energy losses pertaining to redundancy units are inevitably reduced. Future increases in demand can also be easily and cost effectively addressed by simply adding further modules to the system. A variation to the 'one size' modular formation is a mixed capacity approach that utilises different size units to create agility in operational performance. This configuration allows one or more individual units to be automatically selected to best match the specific load requirements of the building. The application of the above strategies can be applied across a large range of heating and cooling, building service systems. Alternative systems may also be considered to provide system resilience rather than using traditional like-for-like redundancy. Table 1. provides examples of alternative solutions against the standard 'doubling up' redundancy practice that often results in oversizing and unnecessary standing losses; these examples have been taken from a mix of published literature (Oughton and Wilson, 2015) and the author's experience of building service systems.

Table 1. Alternative redundancy options

\begin{tabular}{|l|c|}
\hline $\begin{array}{l}\text { Standard HVAC } \\
\text { Redundancy Solution }\end{array}$ & Alternative System(s) to Provide Redundancy \\
\hline $\begin{array}{l}\text { Centralised boiler } \\
\text { arrangement providing } \\
\text { 'N }+1 \text { ' resilience. }\end{array}$ & $\begin{array}{l}\text { - Localised electric heating equipment to provide heat to critical areas. } \\
- \text { Solar hot water, ground/air source heat pumps, biomass boilers to } \\
\text { supplement heating load whilst providing redundancy solution. }\end{array}$ \\
\hline $\begin{array}{l}\text { Centralised cooling } \\
\text { plant providing 'N }+1 ' \\
\text { resilience }\end{array}$ & $\begin{array}{l}\text { - Localised DX plant (split-systems, 'through the wall' units) used as } \\
\text { backup air conditioning in critical areas. Implementing a system } \\
\text { which uses 'free cooling' alongside a cooling storage solution. }\end{array}$ \\
\hline $\begin{array}{l}\text { Backup Electrical } \\
\text { Generators. }\end{array}$ & $\begin{array}{l}\text { - Gas-fed CHP systems used to supplement general electrical } \\
\text { requirements, but switched to feed critical areas in emergencies. } \\
- \text { Solar Photovoltaics and small-scale Wind Turbines to supplement } \\
\text { load whilst providing redundancy solution. }\end{array}$ \\
\hline
\end{tabular}

Another design consideration (specifically for larger sites) would be a centralised solution (i.e. on-site energy centre) providing district heating and cooling, hence only requiring a single redundancy solution, opposed to applying multiple HVAC redundancy solutions boilers/chillers/generators, spread across a single site; this also negates the application of additional margins across the multiple backup systems. A further advantage of the centralised system is its ability to extend system boundaries enabling power to be exported to the wider grid, when electricity generated on-site exceeds that which is required locally.

\subsection{Installation margins - (installers uplift - next size up) - RIBA Stage 5}

Once finalised, the detailed design specification is passed to the main construction contractor for installation. Whilst the design specification will dictate the system capacity, very often it will not provide any specific detail as to how this should be achieved, leaving the choice and selection of plant to the installing contractor. The 'scope of choice' within building service systems to meet a given requirement is vast, and the option selected will have a marked impact on the 'installer' margins applied. Because building services plant is only manufactured in specific capacity ranges, there is often a trade-off 
between efficiency and risk, hence it is standard practice to select the 'next size up' component to ensure peak capacity requirements are met, rather than taking the risk to downsize for the benefit of efficiency. Clearly from an oversizing and efficiency perspective it is imperative that plant capacity 'up-lift' be avoided. This should be facilitated through greater transparency and better communications between stakeholder groups, allowing installers to make informed decisions about equipment sizing.

\subsection{Transparency in the decision-making processes}

The issue of oversizing and the impact this has on energy performance, points to a strong need to manage, track and communicate the application of margins across the entire project development cycle. The design process for the implementation of building service systems follows certain rules and heuristic decision-making practices. Adopting processes that in the first instance captures the scope of margins applied and the rationale for their inclusion; and secondly, communicates this knowledge in a transparent and unambiguous format, will allow stakeholders to manage, sign up on, or if necessary question the margins, enabling them to make informed decisions over equipment sizing and system configuration.

\section{DISSCUSSION AND CONTRIBUTIONS}

Examples presented in section 5, illustrate that building services can incur huge oversizing without stakeholders being aware of this; clients do not understand the purchasing and running cost implications of oversized systems, and the people involved in providing technical solutions are not aware of the margins others have already added. The problem is exacerbated in the context of NHS hospitals by decision makers who are motivated by mitigation against medical risks. The paper highlights several key contributors to the issue of oversizing. One such contributing factor is that despite the fact there are a large range of typical margin values cited within building services technical guides, there is very little published guidance on how best to apply these margins, leaving building service consultants to decide on this, based on experience and intuition. This non-systematic approach to the application and eventual cumulation of design margins hence leads to system excess, and overdesign. The lack of communication and transparency across project stakeholder groups and work phases as seen in Figure 1, is another significant factor leading to overdesign. As the project progresses between work stages, the scope of margins applied, and assumptions made are not necessarily transferred; very often to protect intellectual property rights between the various companies and contractors involved in the project. The mitigation of risks, and the financial benefits to $\mathrm{M} \& \mathrm{E}$ design consultancies and installing contractors resulting from the development of larger, overdesigned systems, are other possible factors as to why the issue of oversizing within the building services industry, is not being addressed. The idea of setting a 'single' joint margin covering all risks rather than accumulating individual margins is something that should be considered. This has the potential of reducing overdesign on all building stock, in general, thus reducing both the initial capital cost and running costs of buildings. Furthermore, the provision of design guidance for building services to address risk and provide flexibility whilst avoiding overdesign, is also required. Finally, as one of the reasons for huge margins, is like-for-like redundancy, the development of alternative design solutions that apply diversity principles, such as different backup systems to provide resilience, should be explored and where possible adopted.

\section{CONCLUSION AND FURTHER WORK}

Hospital Trusts need support to design 'fit for purpose' building service systems for new and refurbished installations that provide the necessary resilience, safety and functionality; all within the finite budget constraints of the NHS. Oversizing has a direct impact on the purchasing, operation, maintenance and replacement cost of building service systems. Processes for defining suitable margins therefore need to be developed. This will require the collaboration of NHS Trusts, design practitioners and the construction industry to establish the stakeholders, their information needs, the data that might be available and the points during project development, when margins need to be considered. Building on the information gained from collaboration, future work could include the development of a digital tool to track margins and their rationales, this will provide key stakeholders with a clear and transparent overview of the margins applied, allowing Trusts to assess the impact of potential changes. A digital system and processes put in place for hospitals can then be applied to other potentially simpler contexts, such as office buildings, universities and schools both within the UK and internationally. 


\section{REFERENCES}

Almefelt, L. (2005), "Balancing properties while synthesising a product concept-a method highlighting synergies", Proceedings ICED'05 / the 15th International Conferenceon Engineering Design, Melbourne, Australia, August 15-18, 2005.

Bacon, M. (2014), "Occupancy analytics: a new basis for low-energy-low-carbon hospital design and operation in the UK". Architectural Engineering and Design Management, Vol. 10 No. 1-2, pp. 146-63.

Banerjee, P. and de Weck, O. (2004), "Flexibility strategy-valuing flexible product options", Proceedings of INCOSE/ICSE conference on synergy between systems engineering and project management, Las Vegas, Nevada.

Bownass, D. (2001), "Building services design methodology”, A Practical Guide, SPON Press, London. https://doi.org/10.4324/9780203478707

Carbon Trust. (2010), "Hospitals: Healthy budgets through energy efficiency".

Chen, C. and Crilly, N. (2014), "Modularity, redundancy and degeneracy: cross-domain perspectives on key design principles". 8th Annual IEEE Systems Conference (SysCon), Ottawa, Canada, IEEE, pp. 546-553.

CIBSE. (1986), "Volume B - Installation and Equipment Data", CIBSE, London.

CIBSE. (1998), "Engineering design calculations and the use of margins", CIBSE, London.

CIBSE. (2006), “Guide A - Environmental design”, CIBSE, London.

Crozier, B. (2000), Enhancing the Performance of Oversized Plant (AG 1/2000), BSRIA, Berkshire. de Neufville, R., de Weck, O., Frey, D., Hastings, D., Larson, R. et al. (2004), "Uncertainty management for engineering systems planning and design”, Engineering Systems Symposium, March 29-31, 2004.

De Neufville, R., Scholtes, S. and Wang, T. (2006), "Real options by spreadsheet: parking garage case example". Journal of infrastructure systems, Vol. 12 No. 2, pp. 107-111.

Department of Health, (2013), "Health technical memorandum 03-01: specialised ventilation for healthcare premises - part a: design and validation".

Djunaedy, E., van den Wymelenberg, K., Acker, B. and Thimmana, H. (2011), “Oversizing of HVAC System: Signatures and Penalties". Energy and Buildings Vol. 43 No. 2-3, pp. 468-475.

Dieter, G.E. (1989), "Mechanical metallurgy”, SI Metric Edition. McGraw-Hill.

Eckert, C.M., Earl, C.F., Lebjioui, S. and Isaksson, O. (2013), "Components margins through the product lifecycle". In IFIP International Conference on Product Lifecycle Management. Springer, Berlin, Heidelberg, (pp. 39-47)

Eckert, C.M. and Isaksson, O. (2017), "Safety Margins and Design Margins: A Differentiation between Interconnected Concepts", Procedia CIRP, Vol. 60, pp. 267-272.

Isaksson, O., Lindroth, P. and Eckert, C.M. (2014), "Optimisation of products versus optimisation of product platforms: an engineering change margin perspective". In DS 77: Proceedings of the DESIGN 2014 13th International Design Conference.

Jones, D.A. and Eckert, C.M. (2016), "Design Margins: Impact on Building Energy Performance Proceedings of the DESIGN 2016 / 14th International Design Conference”, The Design Society, Glasgow, pp. 1295-1304.

Jones, D. and Eckert, C.M. (2017), "Overdesign in Building Services: The Hidden Energy Use", In: Proceedings of the 21st International Conference on Engineering Design (ICED17), Vol. 1: Resource-Sensitive Design| Design Research Applications and Case Studies, Design Society, Vancouver, Canada.

Jones, D.A., Eckert, C.M. and Gericke, K. (2018), "Margins leading to over-capacity", Proceedings of the DESIGN 2018 / 15th International Design Conference, The Design Society, Glasgow, pp.781-792.

Möller, N. and Hansson S.O. (2008), "Principles of engineering safety: Risk and uncertainty reduction", Reliability Engineering and System Safety, Vol. 93 No. 6, pp. 776-783. https://doi.org/10.1016/j.ress.2007.03.031

NHS Sustainable Development Unit (2013), Governance on sustainability: Statutory, Regulatory and Policy Drivers, $S D U$.

Oughton, D. and Wilson, A (2015), "Faber and Kell's heating and air-conditioning of buildings", 11th edition. Taylor and Francis Group, Oxford.

Peeters, L., Van der Veken, J., Hens, H., Helsen, L. and D’haeseleer, W. (2008), “Control of Heating Systems in Residential Buildings: Current Practice”. Energy and Buildings, Vol. 40 No. 8, pp. 1446-1455.

RIBA (2013), "Plan of Work' 66 Portland Place”, London, W1B 1AD. ISBN 9781859465196

Ross, A.M. and Hastings, D.E. (2005), "The tradespace exploration paradigm”. INCOSE International Symposium, Vol. 15 No. 1, pp. 1706-1718. https://doi.org/10.1002/j.2334-5837.2005.tb00783.x

Stratmann, J. (2006), “Engineering Management of Early Stage Warship Design”, PhD thesis, University of Southampton.

Tackett, M.W., Mattson, C.A. and Ferguson, S.M. (2014), “A model for quantifying system evolvability based on excess and capacity”. Journal of Mechanical Design, Vol. 136 No. 5, p. 051002.

Weick, K.E., Sutcliffe, K.M. and Obstfeld, D. (1999), "Organizing for high reliability: Processes of collective mindfulness". Research in Organizational Behaviour, Vol. 21, pp. 81-123. 